\title{
CHOICE OR CONSTRAINT? Women's weekly working hours in comparative perspective
}

Mara Yerkes

ISSR, Univ. Queensland, St. Lucia, Australia and Erasmus Univ. Rot., Rotterdam, the Netherlands

\section{Introduction}

Explanations for cross-national differences and similarities in women's labour market participation can be found in a rich body of sociological research (Bielenski, Bosch and Wagner, 2002; Bruegel and Perrons, 1998; Cipollone and D'Ippoliti, 2011; Crompton, 2006; Crompton and Harris, 1998; Daly, 2000; Fagan and O'Reilly, 1998; Hakim, 1995; 1996; 1998; Nieuwenhuis, Need and Kolk, 2012; Rubery, 1998; Steiber and Haas, 2012; Yerkes, 2010). One key recurring debate within this literature has centred on the issue of choice versus constraint in explaining women's labour market behaviour. In the late 1990s, the sociologist Hakim asserted that individual attitudes and preferences are the primary determinant of the diverse labour market behaviour of women in contemporary western societies (Hakim, $1998 ; 2000)$. This explanation for the variation in women's labour market participation is well-suited to policy changes aimed at increasing women's employment, in pursuit of an adult worker family model (Lewis and Giullari, 2005).

Yet the assumption that preferences are the primary driver of women's employment and the theory built upon it, preference theory, has been criticized by various sociologists (Crompton and Lyonette, 2005; Fagan, 2001; Gash, 2008; Kangas and Rostgaard, 2007; McRae, 2003; Procter and Padfield, 1999; Walters, 2005). In presenting evidence to refute Hakim's theory, these mainly qualitative studies have shown the complexity of individual decision-making, demonstrating the continued presence of individual and household constraints. Kangas and Rostgaard (2007) and Man Yee (2007) have quantitatively addressed the issue of gender roles and attitudes in relation to women's labour market participation, showing the importance of structural constraints. With the exception of Man Yee (2007) and Gash (2008), however, most analyses focus on a cross-sectional analysis of women's employment, which cannot capture the dynamic effects of both preferences and constraints on women's employment patterns. Understanding these complex relationships is important from both a policy and a scientific standpoint. This article addresses this gap by focusing on the question of whether individual working preferences have a causal effect on women's average weekly working hours across time.

Using longitudinal panel data for 1992-2002, this article investigates the effects of working preferences on women's average weekly working hours in the Netherlands, the UK and Germany. Despite relatively high rates of female labour market participation, these three countries have the lowest average weekly working hours 
of women in the EU (OECD, 2012), driven in part by high rates of part-time work. In no country is this more evident than in the Netherlands, where a female labour market participation rate of $73 \%$ masks the highest female part-time work rate of OECD countries: $61 \%$ of Dutch women work part-time (ibid.). This high percentage of part-time work reflects dominant social and economic norms among many Dutch women, both with and without children (Portegijs and Keuzenkamp, 2008; Yerkes, 2009). Preferences for part-time work are high and levels of involuntary part-time work are low (Baaijens, 2005; Tijdens, 2000). The Netherlands, while exceptional in its part-time work rate, is not alone in having a high percentage of women in part-time work. The Netherlands is closely followed by the UK and Germany, where women's labour market participation is 70\% (in the UK) and 71\% (in Germany), but $38 \%$ of German women and 39\% of British women work part-time (OECD, 2012). The question remains whether these working hours are shaped by individual working preferences, by socio-economic constraints, or both. The next section outlines preference theory before outlining the data and developing hypotheses and expectations based on this theoretical discussion. The results, presented in fourth section ("Results"), demonstrate a number of important theoretical and policy implications, discussed in a final, concluding section.

\section{Preference theory}

Preference theory is based on the premise that women's labour market behaviour can be solely explained by individual attitudes and preferences (Hakim, 1998; 2000; $2002 ; 2003 ; 2007)$. According to Hakim, the increased importance of preferences and attitudes is due to five societal changes, which give women more choices today in comparison to thirty or forty years ago: the contraceptive revolution, the equal opportunities revolution, the growth of the service sector with the increasing importance of white collar occupations, a growth in the importance of secondary earners and an increasing recognition that attitudes, values and preferences are important determinants of people's lifestyle choices in rich, modern societies (Hakim, 2000).

Together, these five changes produce what Hakim terms a "qualitatively different" set of opportunities for women in society, compared to the opportunity structures present in societies before these changes took place. The five societal changes described by Hakim constitute the first of four principles of preference theory. The other three tenets are: (1) women's working patterns and preferences are heterogeneous; (2) this heterogeneity causes conflict among women; and (3) this heterogeneity causes women to respond differently to public policy. Diversity in female labour market patterns is not only a consequence of labour market participation - whether or not someone participates in paid labour - but is also a consequence of a variation in working hours (Yerkes, 2010). Hakim contends that an assumption of homogeneity is problematic and that policy-making cannot easily contend with diverse labour market patterns, as policy aimed at the combination of work and care does not recognize the friction between two conflicting priorities production and reproduction. Hakim argues that some women experience these 
priorities as contradictory, preferring to focus on either one or the other. Based on these assumptions, Hakim creates a typology of three "ideal" categories of women based on their preferences: home-centred, adaptive and work-centred. Home-centred women are primarily focused on children and family and they prefer not to work. Work-centred women, in contrast, are devoted to a career or related activities such as politics or sport. According to Hakim, many women in this category are childless by design. She contends that $20 \%$ of women in western societies are home-centred and $20 \%$ are work-centred. The remaining $60 \%$ are considered by Hakim to be "adaptive" women. This is a diverse group of women who have not yet clearly chosen for a family or a career.

Challenging this view, qualitative sociological research has shown that social structures play an essential role in shaping women's labour market behaviour (Procter and Padfield, 1999). Qualitative research findings have been confirmed by some cross-national, quantitative research, such as studies by Crompton and Harris (1998) and Gash (2008), which establish that employment outcomes are a result of both choice and constraint. Similarly, Kangas and Rostgaard (2007) and Man Yee (2007) have shown that individual attitudes do matter, but alongside both structural and institutional factors. The discussion of preference theory resulted in a renewed sociological debate regarding the labour market differences between men and women. While Hakim contends that the differences in labour market outcomes are a result of intrinsic gender differences, critics of this view argue that gender differences are socially constructed (Crompton and Lyonette, 2005; 2007; Hakim, 2007). This article continues in the sociological tradition, taking a quantitative approach to understanding the impact of women's working preferences on average weekly working hours to determine if, as suggested by Hakim, women's labour market participation is primarily explained by individual preferences and attitudes. At the same time, it allows for the importance of social structures, which are known to shape women's labour market participation (see, for example, De Henau, Meulders and O'Dorchai, 2006; Fagan and Rubery, 1996; Lippe and Dijk, 2001; Yerkes, 2010).

This article compares the Netherlands, Germany and the United Kingdom. The reason for choosing these countries is twofold. First, as noted above, these three countries share a similarity in female labour market participation. All three countries have relatively high rates of female labour market participation that obscures high part-time work rates among women. Second, these three countries differ in institutional contexts. The UK is a liberal welfare state (Esping-Andersen, 1990) with a liberal market economy (Hall and Soskice, 2001). The government does not often intervene in employment issues. Social policy, and family policy in particular, are characterized by the government's laissez-faire approach and a minimum of policies to support the combination of work and care (Wattis et al., 2006). An expansion of family policy has taken place since the late 1990s, particularly focused on low-income households, with significant changes occurring in childcare and leave policies (Fleckenstein and Seeleib-Kaiser, 2011). The analyses presented here, however, use data collected prior to most of these policy changes taking place. 
In contrast to the UK, Germany has a coordinated market economy (Hall and Soskice, 2001) and is in many ways a conservative welfare state (Esping-Andersen, 1990). In conservative welfare states, traditional family norms and values play a large role and family policy is minimal or focused on having care take place within the home. However, like the UK, Germany has recently undergone a significant expansion of family policy, with expansions in both childcare and changes to leave policies (Fleckenstein and Seeleib-Kaiser, 2011), which challenge Germany's label as a "conservative" welfare state in regards to family policy. Again, the analyses here use data collected prior to many legislative changes or expansions in childcare. During the period under consideration here, the German government supported a traditional breadwinner division of paid and unpaid work with a very generous parental leave for families with young children, a leave arrangement primarily used by women (OECD, 2004).

The Netherlands is a hybrid case. Strong social democratic and conservative welfare state tendencies are combined with liberal characteristics and a coordinated market economy (Hall and Soskice, 2001). In terms of the combination of work and care, the Netherlands can be considered a mostly conservative regime type. The family continues to play an important role in care tasks. Although there have been a number of developments in Dutch social policy to facilitate the combination of work and care during the last decade, discussed below, women continue to experience problems in combining the two (Peper, Dulk and Doorne-Huiskes, 2009; Wattis et al., 2006).

\section{Data and hypotheses}

This article uses three sets of longitudinal panel data from 1992-2002, including: the British Household Panel Study (BHPS), the German Socio-Economic Panel (GSOEP) and the OSA Labour Supply Panel for the Netherlands (OSA Arbeidsaanbodpanel). The British and German data are annual panels; the Dutch data are collected every two years. This annual data (and for the Netherlands two-year data) are pooled from 1992 to 2002. The sample is restricted to female respondents of working age, aged 15 to 64 years, excluding full-time students and retirees.

\section{Hypotheses}

With preference theory, Hakim is arguing that the social changes of the previous decades have created improved opportunity structures for women. Therefore, labour market patterns are a consequence of individual choice, represented in individual attitudes and preferences. If this is correct, individual preferences should have a significant effect on women's labour market behaviour. Labour market behaviour is measured here as average weekly working hours, and is the dependent variable in all analyses. This variable is based on contractual hours, excluding overtime. In the data used here, in 1992, British women worked an average of 29 hours a week; in the Netherlands and Germany women worked 27 hours a week and 34 
hours a week respectively. By 2002, women's average weekly working hours had decreased slightly in the Netherlands and increased slightly in the UK. By 2002, British women worked an average of 30 hours a week, and Dutch women 25 hours a week. The average weekly working hours of German women show the largest change - by 2002, German women worked an average of 31 hours a week.

The key independent variable of interest is women's working preferences. Individual preferences are measured here as a preference for more, fewer or the same working hours. Respondents in each panel were asked to evaluate their current working hours, and based on these current working hours to answer if they would prefer a change to their working hours. The preference questions as asked in the three datasets are:

BHPS: Thinking about the hours you work, assuming that you would be paid the same amount per hour, would you prefer to: work fewer hours than you do now; work more hours than you do now; or carry on working the same number of hours?

GSOEP: If you could choose your own number of working hours, taking into account that your income would change according to the number of hours: how many hours would you want to work?

OSA ${ }^{1}$

(1) Imagine that you can decide how many hours you work per week. In other words, the number of agreed upon hours you want with your employer. How many hours would you like to work in your current job, if, on average, you would earn the same amount per hour as you do now? If you choose to work less, that means a smaller net income; more work means more income.

(2) I'd like to ask you if you are satisfied with the current breadth of your workweek or if you would like to work more or less. Would you like to continue to work the same amount of hours you work now, or more or less? (2a) How many hours more per week?

(2b) How many hours less per week?

(3) I'd like to ask you if you are satisfied with the current breadth of your workweek or if you would like to work more or less. Imagine that your hourly wage remains the same and that other members within your household do not start working more or fewer hours. Would you like to continue working the same amount of hours you work now, or more or less? (3a) How many hours more per week? (3b) How many hours less per week?

In the BHPS, respondents have been asked to provide a categorical answer of preferring more, fewer or the same hours, so this simplified categorization is used for the analyses here. To minimize causality problems between labour market behaviour and preferences, preferences from the previous period $(t-1)$ are used in

1 Preference questions in the OSA panel changed slightly from 1992-2002. All variations of the questions are presented here. Original emphasis, author's own translation. 
the analyses. ${ }^{2}$ A preference for the same hours is the reference category. In the Netherlands and the UK, most women demonstrate a preference to maintain their weekly working hours; in Germany, a small majority of women has a preference for fewer weekly working hours (see Appendix). If Hakim's preference theory is correct, individual working preferences will have a strong, significant effect on women's individual working hours, which leads to the following three hypotheses: (1) a preference for more hours should cause a significant increase in women's weekly working hours across time; (2) a preference for fewer hours should cause a significant decrease in women's weekly working hours across time; (3) in accordance with preference theory, minor differences in the effect of preferences cross-nationally are likely, given differences in institutional contexts. If preference theory is correct, these hypotheses should hold in both a parsimonious model, measuring the effect of preferences on working hours, as well as a multivariate model, which controls for a number of socio-economic characteristics.

Critics of preference theory assert, however, that individual attitudes and preferences have little to no effect on women's labour market behaviour. Rather, women's labour market behaviour is shaped by social structures, evident in individual and household characteristics such as education or motherhood. To test these conflicting theoretical explanations, four key socio-economic characteristics are included: educational level, marital status, motherhood and age across the life course. The analyses also control for year effects and a number of job characteristics in the analyses: previous labour market pattern in $t-1$, and sector and contract differences. Educational level, a measure of individual human capital investment, is an influential determinant of women's working hours (De Henau, Meulders and O'Dorchai, 2006; Fagan and Rubery, 1996). Controlling for preferences and other factors, the fourth hypothesis is thus: the higher the educational level, the higher the average weekly working hours. Educational level is categorised here as high (university), intermediate (secondary education) and low (less than secondary education) based on the internationally comparable CASMIN-scale (Bernardi, Gangl and van de Werfhorst, 2004; Kerckhoff, Ezell and Brown, 2002; Müller, 2005). The highest category is taken as the reference category.

Research has also shown that motherhood plays a role in determining women's working hours (Mandel and Semyonov, 2006; Yerkes, 2010). The effect of motherhood differs across countries, however, dependent upon the supply of childcare, leave arrangements, school opening times and cultural values. For example, Uunk, Kalmijn and Muffels (2005) demonstrate that the effect of motherhood on women's labour market participation is less negative in countries with a generous supply of public childcare. A study by De Henau, Meulders and O'Dorchai (2006) also shows cross-national variation in the effects of having children and in the effects of the age of the youngest child. The analyses here measure possible cross-national variation in the effect of motherhood using two variables: the number of children under the age of 16 still living in the household, and the age of the youngest child $(0-2,3-5,6+)$. "No

2 Respectively $t-2$ in the Netherlands. 
children" is the reference category for both variables. The effect of motherhood is arguably more complex than the presence and age of children represent. Dominant care ideologies vary significantly across cultures (Kremer, 2006) and ideally, the analyses would account for these cultural norms. We lack such data; however this remains an important issue for further research.

Given the institutional variation in family policies, however, cross-national differences regarding the effects of motherhood are expected. During the period under analysis, Germany had the most generous parental leave scheme of all three countries, stimulating mothers with young children to stay at home to care (Yerkes, 2010). In the UK, the combination of work and care is difficult. Childcare is expensive and plagued by long waiting lists (Wattis et al., 2006). Despite the introduction of new leave arrangements and flexible working hours during the period researched here, possibilities for leave were scarce and often unpaid (id., ibid.). In the Netherlands, the supply of childcare significantly expanded during this period ${ }^{3}$ (CBS, 2007) and new forms of leave possibilities were introduced, yet the use of formal childcare was low (Portegijs et al., 2006; SCP, 2006) and problems with school opening times remain. Given these differences, hypothesis 5 is divided into two subparts. Hypothesis 5a: in the Netherlands and the UK, a negative relationship is expected between motherhood and weekly working hours, regardless of children's age. In Germany, however, this relationship is likely dependent upon the age of the youngest child. Therefore hypothesis $5 b$ for Germany: the younger the child, the lower the average weekly working hours are likely to be.

Being partnered can also influence women's labour market participation. For example, the structure of tax systems can negatively influence married women's labour market participation (Gustafsson, 1996). Research has shown that tax systems which support a single breadwinner model have a negative influence on women's labour market participation $\left(\mathrm{O}^{\prime}\right.$ Donoghue and Sutherland, 1999; Plantenga and Hansen, 1999). Moreover, studies have demonstrated that joint tax systems, whereby the income of the second earner is added to the income of the main earner and is therefore taxed at a much higher rate, lead to a decrease in women's labour market participation (Gustafsson, 1992; 1996). A bivariate dummy variable is used to measure the influence of marital status on women's average weekly working hours here, including married / cohabitating and single / divorced / widowed (the reference category). We again have varying hypotheses by country. Hypothesis $6 a$ : in the UK, which has a fully individualised tax system, marital status is likely to have no effect on average weekly working hours. In contrast, Germany has a joint spouse-based splitting tax system and the Netherlands has a partially individualised system, where tax breaks specifically directed at married couples still exist. Therefore, hypothesis $6 \mathrm{~b}$ is that being married is likely to be negatively related to women's average weekly working hours in Germany and the Netherlands.

3 Comparatively, the aggregate supply of childcare in the Netherlands started at a relatively low level. 
Labour market participation varies across the life course (Groot and Breedveld, 2004; Keuzenkamp, Breedveld and Cloïn, 2004). The analyses control for age across five different life course phases: $15-24 ; 25-34 ; 35-44 ; 45-54 ; 55-64$. Women aged 35-44 are the reference category. The analyses include four remaining control variables: year effects, previous labour market pattern, sector and contract type. Year effects are measured here as a period effect, using a linear variable to control for the period 1992-2002. Previous labour market patterns can also be a partial determinant of current working hours or individual preferences, so it is important to control for this in the analyses. This is controlled for by including the previous labour market pattern in year $t-1$, differentiating between four types of working hours: marginal part-time jobs (0-11 hours), short hours part-time jobs (12-19 hours), long hours part-time jobs (20-34 hours) and full-time jobs (35+ hours). Marginal part-time job is the reference category. Sector is controlled for using a bivariate dummy variable: public and private sector (the reference category). Contract is also controlled for with a bivariate dummy variable: temporary / fixed-term and permanent contract (the reference category). The relationships between these variables and the dependent variable are analysed by applying a fixed-effects model with pooled data from 1992-2002, which reduces the problems associated with pooling individual panel data across time by correcting for unobserved heterogeneity. The models are run separately for each country.

\section{Results}

The first step in the analysis is to examine the potential of Hakim's argument that individual preferences determine women's labour market behaviour. In the most parsimonious model, measuring average weekly working hours as the dependent variable, and a preference for more or fewer hours as the independent variable, working preferences have little effect (see Table 1). In addition, the results are opposite of what is expected, with the exception of the Netherlands. In the Netherlands, a preference for more hours leads to an increase in average weekly working hours of $8 \%$. But a preference for fewer hours has no significant effect on Dutch women's average weekly working hours.

The British and German results contrast with the Dutch data. In both countries, a preference for more hours leads to a decrease in women's average weekly working hours. And a preference for fewer hours leads to an increase in average weekly working hours. These results suggest that the influence of preferences is only visible after controlling for individual, household and job characteristics. The results of this second analysis can be found in Table 2.

After controlling for individual, household and job characteristics, a preference for more hours leads to a small, but significant increase in women's average weekly working hours across time in all three countries. In the Netherlands, a preference for more hours leads to an increase in average weekly working hours of nearly $8 \%$ across time. This result is clearly in line with the parsimonious model shown in Table 1. However, a preference for fewer hours 
The effect of preferences on women's average weekly working hours

\begin{tabular}{|c|c|c|c|c|}
\hline & & Netherlands & UK & Germany \\
\hline & & Coef. (SE) & Coef. (SE) & Coef. (SE) \\
\hline \multicolumn{5}{|c|}{ Lagged preference (ref.: same hours) } \\
\hline & $\begin{array}{l}\text { More hours } \\
\text { Fewer hours }\end{array}$ & $\begin{array}{l}.079^{* * *} \\
(.018) \\
-.015 \\
(.015)\end{array}$ & $\begin{array}{l}-.034^{* * *} \\
(.008) \\
.027^{* * *} \\
(.005)\end{array}$ & $\begin{array}{l}-.006^{\star \star *} \\
(.004) \\
.024^{* * *} \\
(.004)\end{array}$ \\
\hline $\mathrm{N}$ & & 5350 & 27304 & 23875 \\
\hline R2 within & & .010 & .003 & .004 \\
\hline $\mathrm{R} 2$ between & & .021 & .082 & .134 \\
\hline R2 overall & & .020 & .060 & .073 \\
\hline
\end{tabular}

$\sim p<.10,{ }^{*} p<.05,{ }^{* *} p<.01,{ }^{* * *} p<.001$.

Source: British Household Panel Study, German Socio-Economic Panel, OSA Labour Supply Panel 1992-2002.

still has no significant effect on women's average weekly working hours in the Netherlands. It should be noted, however, that Dutch employees can adjust their working hours with relative ease. Legislation passed in 2000, under the Working Hours Adjustment Act (Wet Aanpassing Arbeidsduur), gives individual employees the right to increase or decrease their working hours following one year of employment with the same employer. Even prior to the passage of legislation in 2000, a majority of Dutch employees had the capacity to adjust their working hours within the boundaries of collective agreements. In combination with the gendered part-time culture existent in the Netherlands (Yerkes, 2009), this context could lead to an underestimation of the number of individuals with a preference for fewer hours. These results for the Netherlands are similar to findings from Gash (2008), which suggest that opportunity structures present in Denmark are better than those found in the UK and France, making it easier for individuals to attain work and care preferences.

Similar to the Dutch situation, a preference for more hours has a significant effect on British and German women's average weekly working hours. Therefore, the first hypothesis is confirmed. In the UK, women with a preference for more hours work 3\% more across time; in Germany, it leads to an increase of $2 \%$. A preference for fewer hours does not cause a significant adjustment of weekly working hours in the UK, but it does lead to a small, but significant increase in women's average weekly working hours in Germany. Consequently, hypothesis two is rejected. These results suggest that the Dutch institutional context, in which preferences are influential in increasing working hours but less influential in a downwards adjustment, is different from the German and British institutional contexts, partially confirming hypothesis 3 . 
Table 2

Fixed-effects results

\begin{tabular}{|c|c|c|c|}
\hline \multicolumn{4}{|c|}{ Average weekly working hours } \\
\hline & Netherlands & UK & Germany \\
\hline & Coef. (SE) & Coef. (SE) & Coef. (SE) \\
\hline \multicolumn{4}{|c|}{ Previous working hours (ref.: 0-11 hours) } \\
\hline $12-19$ hours & $\begin{array}{l}-.054 \\
(.034)\end{array}$ & $\begin{array}{l}.171^{* \star \star} \\
(.011)\end{array}$ & $\begin{array}{l}.044^{* *} \\
(.013)\end{array}$ \\
\hline 20-34 hours & $\begin{array}{l}-.049 \\
(.034)\end{array}$ & $\begin{array}{l}.289^{* \star \star} \\
(.011)\end{array}$ & $\begin{array}{l}.151^{* * *} \\
(013)\end{array}$ \\
\hline $35+$ hours & $\begin{array}{l}-.050 \\
(.035)\end{array}$ & $\begin{array}{l}.353^{\star \star \star} \\
(.011)\end{array}$ & $\begin{array}{l}.246^{\star \star \star} \\
(.013)\end{array}$ \\
\hline \multicolumn{4}{|c|}{ Lagged preference (ref.: same hours) } \\
\hline More hours & $\begin{array}{l}.077^{\star \star *} \\
(.019)\end{array}$ & $\begin{array}{l}.034^{* \star *} \\
(.007)\end{array}$ & $\begin{array}{l}.018^{* \star *} \\
(.005)\end{array}$ \\
\hline Fewer hours & $\begin{array}{l}. .001 \\
(.017)\end{array}$ & $\begin{array}{l}.003 \\
(.005)\end{array}$ & $\begin{array}{l}.009^{*} \\
(.004)\end{array}$ \\
\hline \multicolumn{4}{|c|}{ Educational level (ref.: high) } \\
\hline Low & $\begin{array}{l}-.024 \\
(.036)\end{array}$ & $\begin{array}{c}-.084^{\star \star *} \\
(.017)\end{array}$ & $\begin{array}{l}-.030 \\
(.016)\end{array}$ \\
\hline Intermediate & $\begin{array}{l}-.013 \\
(.031)\end{array}$ & $\begin{array}{c}-.045^{\star \star \star} \\
(.012)\end{array}$ & $\begin{array}{l}-.019 \\
(.010)\end{array}$ \\
\hline \multicolumn{4}{|l|}{ Age (ref.: $35-44)$} \\
\hline $15-24$ & $\begin{array}{l}.092 \\
(.052)\end{array}$ & $\begin{array}{l}-.012 \\
(.015)\end{array}$ & $\begin{array}{l}.001 \\
(.014)\end{array}$ \\
\hline $25-34$ & $\begin{array}{l}-.025 \\
(.029)\end{array}$ & $\begin{array}{l}-.021^{*} \\
(.009)\end{array}$ & $\begin{array}{l}.004 \\
(.008)\end{array}$ \\
\hline $45-54$ & $\begin{array}{l}-.029 \\
(.030)\end{array}$ & $\begin{array}{l}.007 \\
(.010)\end{array}$ & $\begin{array}{l}.015 \\
(.008)\end{array}$ \\
\hline $55-64$ & $\begin{array}{l}-.168^{\star *} \\
(.057)\end{array}$ & $\begin{array}{l}-.043^{* *} \\
(.016)\end{array}$ & $\begin{array}{l}.015 \\
(.013)\end{array}$ \\
\hline \multicolumn{4}{|c|}{ Number of children in $\mathrm{HH}$ under 16 (ref.: none) } \\
\hline 1 child & $\begin{array}{c}-.262^{\star * *} \\
(.028)\end{array}$ & $\begin{array}{c}-.091^{* * *} \\
(.014)\end{array}$ & $\begin{array}{c}-.036^{* * *} \\
(.009)\end{array}$ \\
\hline 2 children & $\begin{array}{c}-.286^{* * *} \\
(.028)\end{array}$ & $\begin{array}{c}-198^{* * *} \\
(.016)\end{array}$ & $\begin{array}{c}-.062^{* \star *} \\
(.013)\end{array}$ \\
\hline $3+$ children & $\begin{array}{c}-.203^{\star \star \star} \\
(.044)\end{array}$ & $\begin{array}{c}-.305^{\star \star \star} \\
(.021)\end{array}$ & $\begin{array}{c}-.061^{\star \star} \\
(.023)\end{array}$ \\
\hline \multicolumn{4}{|c|}{ Age of youngest child (ref.: no children) } \\
\hline $0-2$ years old & $\begin{array}{l}-.023 \\
(.027)\end{array}$ & $\begin{array}{c}-.170^{* * *} \\
(.015)\end{array}$ & $\begin{array}{c}-.276^{\star * *} \\
(.018)\end{array}$ \\
\hline $3-5$ years old & $\begin{array}{l}-.072^{*} \\
(.029)\end{array}$ & $\begin{array}{c}-.135^{\star \star *} \\
(.015)\end{array}$ & $\begin{array}{c}-.128^{* \star *} \\
(.013)\end{array}$ \\
\hline $5-15$ years old & $\begin{array}{l}-.048^{\star} \\
(.022)\end{array}$ & $\begin{array}{l}.025 \\
(.014)\end{array}$ & $\begin{array}{c}-.034^{\star \star *} \\
(.009)\end{array}$ \\
\hline \multicolumn{4}{|c|}{ Marital status (ref.: single) } \\
\hline Married/cohabitating & $\begin{array}{l}.026 \\
(.046)\end{array}$ & $\begin{array}{l}-.007 \\
(.008)\end{array}$ & $\begin{array}{c}-.048^{\star \star \star} \\
(.008)\end{array}$ \\
\hline \multicolumn{4}{|c|}{ Contract type (ref.: permanent) } \\
\hline Temporary & $\begin{array}{c}-.067^{\star \star} \\
(.024)\end{array}$ & $\begin{array}{c}-.092^{\star \star \star} \\
(.009)\end{array}$ & $\begin{array}{l}.007 \\
(.008)\end{array}$ \\
\hline \multicolumn{4}{|l|}{ Sector (ref.: private) } \\
\hline Public & $\begin{array}{l}.023 \\
(.026)\end{array}$ & $\begin{array}{l}-.021^{*} \\
(.009)\end{array}$ & $\begin{array}{l}.107^{* * *} \\
(.027)\end{array}$ \\
\hline Period effect (linear) & $\begin{array}{l}.006 \\
(.004)\end{array}$ & $\begin{array}{l}.001 \\
(.001)\end{array}$ & $\begin{array}{c}-.004^{\star \star *} \\
(.001)\end{array}$ \\
\hline Intercept & $\begin{array}{c}3.248^{\star * *} \\
(.064)\end{array}$ & $\begin{array}{c}3.181^{* * *} \\
(.018)\end{array}$ & $\begin{array}{c}3.327^{\star * *} \\
(.020)\end{array}$ \\
\hline $\mathrm{N}$ & 3299 & 26163 & 18656 \\
\hline $\begin{array}{l}R^{2} \text { within } \\
R^{2} \text { between } \\
R^{2} \text { overall }\end{array}$ & $\begin{array}{l}.141 \\
.092 \\
.077\end{array}$ & $\begin{array}{l}.152 \\
.383 \\
.368\end{array}$ & $\begin{array}{l}.096 \\
.518 \\
.463\end{array}$ \\
\hline
\end{tabular}

$\sim p<.10,{ }^{*} p<.05,{ }^{* *} p<.01,{ }^{* * *} p<.001$.

Source: British Household Panel Study, German Socio-Economic Panel, OSA Labour Supply Panel 1992-2002. 


\section{Individual and household characteristics}

Although the results presented in Tables 1 and 2 confirm hypothesis 1 and partially confirm hypothesis 3 , a closer examination of the results demonstrates that the data in general refute preference theory and strengthen the arguments and empirical evidence given by critics of preference theory (Crompton and Lyonette, 2005; Fagan, 2001; Kangas and Rostgaard, 2007; McRae, 2003; Procter and Padfield, 1999; Walters, 2005). Individual preferences, in and of themselves, are not the sole determinant of women's average weekly working hours. More importantly, the results demonstrate that individual and household characteristics continue to be more important determinants of labour market behaviour. The effect of motherhood is particularly strong. Controlled for individual preferences, we see a clear trend: mothers in all three countries decrease their working hours across time. Cross-national differences in the effects of motherhood are apparent, however, some of which confirm our expectations. For example, having children has a strong negative effect on Dutch women's working hours - having one child leads to a $26 \%$ decrease in average weekly working hours in comparison to women without children. In the Netherlands, the effect of motherhood decreases as women have more children, and the age of the youngest child only causes small changes to weekly working hours. This is in line with our hypotheses. In the Netherlands, it is common for women to decrease their average weekly working hours following the arrival of a first child. Mothers often remain in part-time work, negating the necessity for another adjustment in working hours if they have additional children (Visser and Yerkes, 2008). For some women, though, a further adjustment of their working hours may not be possible.

Contrary to our hypotheses, the analyses for the UK differ from the Netherlands. As British women have more children, they decrease their working hours even more. In other words, opposite the expectations outlined earlier, there are visible differences between motherhood in the UK and the Netherlands. In the UK, the supply of affordable childcare is lower (Wattis et al., 2006). Moreover, British mothers only recently gained the right to request an adjustment to working hours in 2003. The results from the German data are wholly in line with the expectations outlined above. The most significant effect of motherhood is evident for mothers with young children, a likely consequence of the German institutional context, where, during the period under analysis, mothers had a right to paid parental leave until the child reached the age of three, but were limited in the number of hours they could work while taking leave. This generous leave arrangement has meant that, up until now, the supply of childcare places for children under the age of three was scarce (Fleckenstein and Seeleib-Kaiser, 2011).

The remaining individual and household characteristics show significant, but varying results, suggesting possible differences in institutional contexts. A few noticeable cross-national differences include the discrepancies in the effects of educational level and marital status. Controlled for individual preferences, and 
contrary to our hypotheses, educational level seems to have no significant influence on women's average weekly working hours in the Netherlands or the UK. This could be due to insufficient variation across time within a fixed-effects model. However, we see that British women with less than a university education reduce their average weekly working hours across time, confirmation of a polarized labour market in the UK, where education is often the boundary between good and poor labour market positions. In addition, the expectations regarding marital status are confirmed. In line with our hypotheses, in Germany, where a joint tax system is present, married and cohabitating women decrease their average working hours across time, in comparison to women without a partner. These results are not surprising given that of the three countries analysed here, Germany's tax system maintains the highest support for a single breadwinner model (Dingeldey, 2001; Gustafsson, 1996; OECD, 2002). These results demonstrate the importance of understanding women's labour market behaviour as a combination of individual working preferences, which have a limited effect, and social structures, which significantly shape women's labour market participation.

\section{Job characteristics}

Alongside individual and household characteristics, a number of control variables were also included, which show clear cross-national differences. The explanation for these cross-national differences requires further research, however. Regardless of a woman's previous labour market pattern, in comparison to women with marginal part-time jobs, British and German women increase their average weekly working hours across time. The results also demonstrate that British and Dutch women with a temporary or fixed-term contract experience a significant decrease in average weekly working hours across time, $9 \%$ and $7 \%$ respectively. This difference could be explained by the relatively small temporary employment sector in Germany, in comparison to the Netherlands and the UK. This makes it feasible that no effect is found in Germany. Just the same, temporary work is growing in Germany (Houwing, 2005).

At the same time, a significant sector effect in the UK and Germany is evident. Working in the public sector leads to an increase in German women's average weekly working hours of $11 \%$. This is in contrast to the UK, where working in the public sector leads to a small decrease in women's average weekly working hours across time. These results need to be interpreted with caution. Firstly, the variation in sector type from 1992-2002 could be insufficient to be included as a time-varying coefficient in a fixed-effects model. Second, these results could also reflect some amount of self-selection, with women self-selecting into the public sector due to perceived favourable work and care options, for example. Additional research is needed to explore these possibilities. 


\section{Conclusions}

This article investigated whether individual working preferences had a causal effect on average weekly working hours for Dutch, German and British women. Taking preference theory as a starting point, the hypothesis was that individual preferences would have a strong, significant effect on women's working hours. Giving attention to critiques of preference theory, however, the article also considered the importance of social structures as determinants of women's labour market behaviour. The results demonstrate that although preferences have a significant, causal effect on average weekly working hours, social structural factors, such as motherhood, are stronger determinants of women's working hours. Working hours preferences are most influential in the Netherlands. But even in the Dutch case, we cannot speak of individual labour market "choices" as posed by Hakim.

The results of the analyses presented here are clear. In most cases, individual preferences have a significant effect on women's weekly working hours. Yet these effects are small, and are clearly not the sole determining factor of women's weekly working hours. The effects of social structures, measured in educational level, motherhood, marital status and age across the life course, as well as a number of job characteristics, demonstrate that women's average weekly working hours are shaped by a combination of factors. The effects of these factors differ across countries, however. If we look at individual preferences and their predictive power, the analyses suggest that the Dutch institutional context is qualitatively different from that of Germany or the UK. The Netherlands is characterised by flexible working hours legislation, favourable labour market circumstances and a culture in which adjusting working hours, particularly to reduced hours or part-time work, is normal (Yerkes, 2009). From the starting point in the analyses, the Dutch results follow theoretical expectations. Despite the absence of a significant effect of a preference for fewer hours, the causal direction remained evident. Additional research is necessary, but it is plausible that Dutch institutional and policy structures are more conducive to realising individual working preferences, as is the case with Denmark in Gash's (2008) study. However, various constraints continue to influence women's labour market decisions, even in the Netherlands. The results show that the relationship between individual preferences and labour market participation is complex, and cannot be reduced to a parsimonious argument that individual preferences determine labour market participation.

At the same time, further research is needed to investigate the complexity of the relationship between individual preferences and labour market participation. The analyses performed here, for example, do not correct for preference duration or the realisation of preferences (see Baaijens, 2005). Moreover, additional research can investigate the general context in which preferences are formed and realised. Dutch women have a greater amount of flexibility with their working hours, which seems to increase the predictive power of individual preferences. The labour market environment in Germany and the UK seems to be less conducive to the realisation of preferences. Revisiting these analyses as more recent data become available 
will be crucial to unpacking these complex relationships, particularly given recent policy changes in these countries.

In line with recent research from Gash (2008), the results presented here demonstrate that it is important to consider preferences in combination with social structural factors, and within varying institutional contexts. The data presented here show a clear difference between the Netherlands on the one hand, and Germany and the UK on the other. Although further research is needed to exclude alternative explanations for these cross-national differences, it is plausible that many of the differences found here are due to differences in institutional structures and policies. It is particularly important to account for this variation for two reasons: the global financial crisis and the continued development of policies centred on improving women's employment.

The recent global financial crisis (GFC) adds increased complexity to understanding women's employment. Job cuts in sectors overrepresented by women (e.g. the public sector) or men (e.g. manufacturing) can impact women's employment in various ways. Women may prefer longer part-time or full-time hours if their partner loses their job. In addition, women may be directly impacted by job cuts in the public sector. International comparative data on women's representation in public sector employment is often problematic due to varying definitions (Hammouya, 1999). But in countries like the US or Finland (id., ibid.) or Australia (Colley, 2011) and certainly others, where women represent a significant proportion of public sector workers, cuts to public sector employment can negatively impact women's labour market participation and their working hours. In the case countries considered here, for example, the proportion of women in public sector employment in the UK and Germany is nearly two-thirds, therefore women in these countries are more vulnerable to public sector employment cuts than in the Netherlands, where the proportion is significantly lower (Hicks et al., 2005).

Lastly, national level policies aimed at increasing women's labour market participation or facilitating work-care combinations continue to develop. All three countries studied here, as is the case in most European countries, have undergone profound policy changes in recent years, including the introduction of various (paid) leave forms, flexible working arrangements, tax cuts, childcare subsidies and so forth. While the effect of these policies on women's employment is not always clear (Cooke and Baxter, 2010), policy-makers continue to push for improvements in women's participation and working hours. Understanding the relationship between work and care preferences in relation to individual constraints within given institutional contexts will not only inform the theoretical debate on this topic but inform these policy developments as well. Consideration for specific institutional and cultural issues that shape women's labour market participation will help increase individual "choice" in a labour market of constraints. 
Appendix Mean distributions of independent variables in the Netherlands, the UK and Germany: pooled waves $1992-2002^{(1)}$

\begin{tabular}{|c|c|c|c|c|}
\hline & & NL & UK & GER \\
\hline \multicolumn{5}{|l|}{ Preference } \\
\hline & More hours & 0.15 & 0.08 & 0.25 \\
\hline & Same hours & 0.64 & 0.61 & 0.3 \\
\hline & Fewer hours & 0.21 & 0.31 & 0.45 \\
\hline \multicolumn{5}{|l|}{ Previous working pattern } \\
\hline & $0-11$ & 0.09 & 0.06 & 0.04 \\
\hline & $12-19$ & 0.12 & 0.12 & 0.07 \\
\hline & $20-34$ & 0.34 & 0.25 & 0.25 \\
\hline & $34+$ & 0.45 & 0.57 & 0.63 \\
\hline \multicolumn{5}{|l|}{ Ed. qual. } \\
\hline & High & 0.19 & 0.41 & 0.13 \\
\hline & Intermediate & 0.39 & 0.37 & 0.56 \\
\hline & Low & 0.43 & 0.22 & 0.31 \\
\hline \multicolumn{5}{|l|}{ Marital status } \\
\hline & Single & 0.21 & 0.27 & 0.36 \\
\hline & Married/cohabitating & 0.79 & 0.73 & 0.64 \\
\hline \multicolumn{5}{|l|}{ Age } \\
\hline & $15-24$ & 0.11 & 0.13 & 0.07 \\
\hline & $25-34$ & 0.3 & 0.28 & 0.25 \\
\hline & $35-44$ & 0.3 & 0.27 & 0.32 \\
\hline & $45-54$ & 0.25 & 0.23 & 0.26 \\
\hline & $55-64$ & 0.05 & 0.09 & 0.10 \\
\hline \multicolumn{5}{|l|}{ Number of children } \\
\hline & None & 0.64 & 0.60 & 0.61 \\
\hline & 1 child & 0.09 & 0.20 & 0.23 \\
\hline & 2 children & 0.18 & 0.16 & 0.13 \\
\hline & 3 or more & 0.09 & 0.04 & 0.02 \\
\hline \multicolumn{5}{|l|}{ Age of youngest child* } \\
\hline & No kids & 0.63 & 0.64 & 0.64 \\
\hline & $0-2$ years & 0.09 & 0.09 & 0.01 \\
\hline & $3-5$ years & 0.08 & 0.07 & 0.05 \\
\hline & $6-15$ years & 0.21 & 0.21 & 0.30 \\
\hline \multicolumn{5}{|l|}{ Sector } \\
\hline & Public & 0.19 & 0.37 & 0.05 \\
\hline & Private & 0.82 & 0.63 & 0.95 \\
\hline \multicolumn{5}{|l|}{ Contract type } \\
\hline & Permanent & 0.88 & 0.94 & 0.94 \\
\hline & Temporary & 0.12 & 0.06 & 0.06 \\
\hline \multicolumn{2}{|l|}{ Number of observations } & 3299 & 26163 & 18656 \\
\hline
\end{tabular}

*The mean percentage of women without children is slightly higher for this variable in some cases because of some women who report having children but do not provide the child's age. To create the variable of youngest age of the child, it was necessary to include all "inapplicable" responses as no children.

${ }^{(1)}$ Due to rounding differences, some totals may not equal $100 \%$.

Source: Author's own calculations based on BHPS 1992, 1998, 2002. 


\section{References}

Baaijens, Christine (2005), Arbeidstijden. Tussen Wens en Werkelijkheid, Utrecht, Universiteit van Utrecht.

Bernardi, Fabrizio, Markus Gangl, and Herman G. van de Werfhorst (2004), The from School-to-Work Dynamics. Timing of Work and Quality of Work in Italy, the Netherlands and the United States, 1980-1998, Madrid, Instituto Juan March de Estudios e Investigaciones.

Bielenski, Harald, Gerhard Bosch, and Alexandra Wagner (2002), Working Time Preferences in Sixteen European Countries, Dublin, European Foundation for the Improvement of Living and Working Conditions.

Bruegel, Irene, and Diane Perrons (1998), “Deregulation and women's employment: the diverse experiences of women in Britain", Feminist Economics, 4 (1), pp. 103-125.

CBS - Centraal Bureau voor de Statistiek (2007), Statline (Online Statistical Database), retrieved 29 June, 2007, from CBS (Statistics Netherlands), http://statline.cbs.nl/statweb/

Cipollone, Angela, and Carlo D'Ippoliti (2011), “Women's employment: joining explanations based on individual characteristics and on contextual factors", The American Journal of Economics and Sociology, 70 (3), pp. 756-783.

Colley, Linda (2011), “Not codgers in cardigans! Female workforce participation and ageing public services, Gender, Work \& Organization, early view, DOI: 10.1111/j.1468-0432.2011.00582.x.

Cooke, Lynn Prince, and Janeen Baxter (2010), “'Families' in international context: comparing institutional effects across Western societies", Journal of Marriage and Family, 72 (3), pp. 516-536.

Crompton, Rosemary (2006), Employment and the Family. The Reconfiguration of Work and Family Life in Contemporary Societies, Cambridge and New York, Cambridge University Press.

Crompton, Rosemary, and Fiona Harris (1998), “Explaining women's employment patterns: 'orientations to work' revisited", The British Journal of Sociology, 49 (1), pp. 118-136.

Crompton, Rosemary, and Clare Lyonette (2005), “The new gender essentialism: domestic and family 'choices' and their relation to attitudes", The British Journal of Sociology, 56 (4), pp. 601-620.

Crompton, Rosemary, and Clare Lyonette (2007), "Reply to Hakim", The British Journal of Sociology, 58 (1), pp. 133-134.

Daly, Mary (2000), “A fine balance: women's labour market participation in international comparison", in F. W. Scharpf and V. A. Smith (eds.), Welfare and Work in the Open Economy. Diverse Responses to Common Challenges, Oxford, Oxford University Press, pp. 467-511.

De Henau, Jérôme, Danièle Meulders, and Sile O'Dorchai (2006), The Comparative Effectiveness of Public Policies to Fight Motherhood-Induced Employment Penalties and Decreasing Fertility in the Former EU-15 DULBEA Research Series, Brussels, Université Libre de Bruxelles.

Dingeldey, Irene (2001), “European tax systems and their impact on family employment patterns", Journal of Social Policy, 30 (4), pp. 653-672. 
Esping-Andersen, Gøsta (1990), The Three Worlds of Welfare Capitalism, Cambridge, UK, Polity Press.

Fagan, Colette (2001), “Time, money and the gender order: work orientations and working-time preferences in Britain", Gender, Work and Organization, 8 (3), pp. 239-266.

Fagan, Colette, and Jacqueline O'Reilly (1998), “Conceptualising part-time work: the value of an integrated comparative perspective", in Jacqueline O'Reilly and Colette Fagan (eds.), Part-Time Prospects. An International Comparison of Part-Time Work in Europe, North America and the Pacific Rim, London and New York, Routledge, pp. 1-31.

Fagan, Colette, and Jill Rubery (1996), "The salience of the part-time divide in the European Union", European Sociological Review, 12 (3), pp. 227-250.

Fleckenstein, Timo, and Martin Seeleib-Kaiser (2011), "Business, skills and the welfare state: the political economy of employment-oriented family policy in Britain and Germany", Journal of European Social Policy, 21 (2), pp. 136-149.

Gash, Vanessa (2008), “Preference or constraint? Part-time workers' transitions in Denmark, France and the United Kingdom", Work Employment Society, 22 (4), pp. 655-674.

Groot, Loek, and Koen Breedveld (2004), “Time over the life course: preferences, options and life course policy", Tijdschrift voor Arbeidsvraagstukken, 20 (3), pp. 288-302.

Gustafsson, Siv (1992), "Separate taxation and married womens labor supply: a comparison of West-Germany and Sweden", Journal of Population Economics, 5 (1), pp. 61-85.

Gustafsson, Siv (1996), “Tax regimes and labour market performance”, in G. Schmid, J. O'Reilly and K. Schömann (eds.), International Handbook of Labour Market Policy and Evaluation, Cheltenham and Brookfield, Edward Elgar, pp. 811-839.

Hakim, Catherine (1995), "Five feminist myths about women's employment", The British Journal of Sociology, 46 (3), pp. 429-455.

Hakim, Catherine (1996), “The sexual division of labour and women's heterogeneity”, The British Journal of Sociology, 47 (1), pp. 178-188.

Hakim, Catherine (1998), "Developing a sociology for the twenty-first century: Preference Theory", The British Journal of Sociology, 49 (1), pp. 137-143.

Hakim, Catherine (2000), Work-Lifestyle Choices in the 21st Century. Preference Theory, Oxford and New York, Oxford University Press.

Hakim, Catherine (2002), “Lifestyle preferences as determinants of women's differentiated labor market careers", Work and Occupations, 29 (4), pp. 428-459.

Hakim, Catherine (2003), "Public morality versus personal choice: the failure of social attitude surveys", The British Journal of Sociology, 54 (3), pp. 339-345.

Hakim, Catherine (2007), "Dancing with the Devil? Essentialism and other feminist heresies", The British Journal of Sociology, 58 (1), pp. 123-132.

Hall, Peter A., and David Soskice (eds.) (2001), Varieties of Capitalism. The Institutional Foundations of Comparative Advantage, New York, Oxford University Press.

Hammouya, Messaoud (1999), “Statistics on public sector employment: methodology, structures and trends", ILO Working Papers, Geneva, International Labor Organization. 
Hicks, Stephen, Annette Walling, Daniel Heap, and Donna Livesay (2005), Public Sector Employment Trends, London, Office of National Statistics.

Houwing, Hester (2005), "Variations in flexibility and security-agency work and the role of collective bargaining institutions", paper presented the Second European Doctoral Conference of PhD Students in Labour Studies and Industrial Relations, Milan.

Kangas, Olli, and Tine Rostgaard (2007), "Preferences or institutions? Work family life opportunities in seven European countries", Journal of European Social Policy, 17 (3), pp. 240-256.

Kerckhoff, Alan C., Elizabeth Dietrich Ezell, and J. Scott Brown (2002), “Toward an improved measure of educational attainment in social stratification research", Social Science Research, 31 (1), pp. 99-123.

Keuzenkamp, Saskia, Koen Breedveld, and Mariëlle Cloïn (2004), “Andere tijden voor huishoudens", in SCP (ed.), Sociaal en Cultureel Rapport 2004, The Hague, Social and Cultural Planning Office, pp. 93-128.

Kremer, Monique (2006), “The politics of ideals of care: Danish and Flemish child care policy compared", Soc Pol, 13 (2), pp. 261-285.

Lewis, Jane, and Susanna Giullari (2005), “The adult worker model family, gender equality and care: the search for new policy principles and the possibilities and problems of a capabilities approach", Economy $\mathcal{E}$ Society, 34 (1), pp. 76-104.

Lippe, Tanja van der, and Liset van Dijk (2001), “Women's employment in a comparative perspective", in Liset van Dijk and Tanja van der Lippe (eds.), Women's Employment in a Comparative Perspective, New York, Aldine de Gruyter, pp. 1-17.

Man Yee, Kan (2007), “Work orientation and wives' employment careers: an evaluation of Hakim's Preference Theory", Work and Occupations, 34 (4), pp. 430-462.

Mandel, Hadas, and Moshe Semyonov (2006), "A Welfare State paradox: state interventions and women's employment opportunities in 22 countries", American Journal of Sociology, 111 (6), pp. 1910-1949.

McRae, Susan (2003), “Constraints and choices in mothers' employment careers: a consideration of Hakim's Preference Theory", The British Journal of Sociology, 54 (3), pp. 317-338.

Müller, Walter (2005), CASMIN Education Classification, retrieved February 10, 2005, from http://www.nuf.ox.ac.uk/

Nieuwenhuis, Rense, Ariana Need, and Henk van der Kolk (2012), “Institutional and demographic explanations of women's employment in 18 OECD countries, 1975-1999, Journal of Marriage and Family, 74 (3), pp. 614-630.

O'Donoghue, Cathal, and Holly Sutherland (1999), "Accounting for the family in European income tax systems", Cambridge Journal of Economics, 23 (5), pp. 565-598.

OECD (2002), Taxing Wages. Income Tax, Social Security Contributions and Cash Family Benefits, Paris, OECD.

OECD (2004), Early Childhood Education and Care Policy in Germany, Paris, OECD.

OECD (2012), Labour Force Statistics, from www.oecd.org

Peper, Bram, Laura den Dulk, and Anneke van Doorne-Huiskes (2009), “Work-family policies in a contradictory culture: a Dutch financial sector corporation", in Suzan Lewis, Julia Brannen and Ann Nilsen (eds.), Work, Families and Organizations in Transition. European Perspectives, Bristol, The Policy Press, pp. 113-130. 
Plantenga, Janneke, and Johan Hansen (1999), “Assessing the equal opportunities in the European Union", International Labour Review, 138 (4), p. 351.

Portegijs, Wil, Mariëlle Cloïn, Ingrid Ooms, and Evelien Eggink (2006), Hoe het Werkt met Kinderen. Moeders over Kinderopvang en Arbeidsparticipatie, The Hague, Sociaal Cultureel Planbureau.

Portegijs, Wil, and Saskia Keuzenkamp (eds.) (2008), Nederland Deeltijdland. Vrouwen en Deeltijdwerk, The Hague, Sociaal Cultureel Planbureau.

Procter, Ian, and Maureen Padfield (1999), “Work orientations and women's work: a critique of Hakim's theory of the heterogeneity of women", Gender, Work $\mathcal{E}$ Organization, 6 (3), pp. 152-162.

Rubery, Jill (1998), Women and European Employment, London and New York, Routledge. SCP - Sociaal Cultureel Planbureau (2006), Emancipatiemonitor 2006, The Hague, SCP.

Steiber, Nadia, and Barbara Haas (2012), “Advances in explaining women's employment patterns", Socio-Economic Review, 10 (2), pp. 343-367.

Tijdens, Kea (2000), “Employment options of the future-actual and preferred working hours", National Working Paper for the Netherlands, Dublin, Eurofound.

Uunk, Wilfred, Matthijs Kalmijn, and Ruud Muffels (2005), “The impact of young children on women's labour supply: a reassessment of institutional effects in Europe", Acta Sociologica, 48 (1), pp. 41-62.

Visser, Jelle, and Mara A. Yerkes (2008), "Part-time work and the legacy of breadwinner Welfare States", in L. Kenworthy and A. Hicks (eds.), Methods and Substance in Macrocomparative Analysis, New York, Palgrave Macmillan, pp. 221-259.

Walters, Sally (2005), "Making the best of a bad job? Female part-timers' orientations and attitudes to work", Gender, Work E Organization, 12 (3), pp. 193-216.

Wattis, Louise, Mara A. Yerkes, Susanna Lloyd, Manuela Hernandez, Louise Dawson, and Kay Standing (2006), Combining Work and Family Life. Removing the Barriers to Women's Progression. Experiences from the UK and the Netherlands, Liverpool, John Moores Liverpool University.

Yerkes, Mara A. (2009), "Part-time work in the Dutch welfare state: the ideal combination of work and care?" Policy and Politics, 37 (4), pp. 535-552.

Yerkes, Mara A. (2010), “Diversity in work: the heterogeneity of women's employment patterns", Gender, Work E Organization, 17 (6), pp. 696-720.

Mara A. Yerkes. Senior research fellow, Employment and Education Program, Institute for Social Science Research, The University of Queensland, also affiliated with the Department of Sociology, Erasmus University Rotterdam.

E-mail: m.yerkes@uq.edu.au 


\section{Resumo/abstract/résumé/resumen}

Escolha ou constrangimento? Horas semanais de trabalho das mulheres em perspetiva comparada

Este artigo analisa a influência das preferências individuais de trabalho no comportamento das mulheres no mercado de trabalho na Holanda, Alemanha e Reino Unido, abordando a questão: até que ponto as preferências individuais têm um efeito causal na média das horas de trabalho semanais das mulheres? Usando dados de painéis longitudinais dos três países, é aplicado um modelo de efeitos fixos para medir o efeito das preferências individuais no ano $t-1$, na média das horas de trabalho semanais das mulheres no ano $t$. Os dados são explorados de 1992 a 2002. Depois de controlar para cada indivíduo as características habitacionais e profissionais, vemos que as preferências individuais são mais influentes na Holanda. No entanto, os dados não sustentam a ideia de que a escolha é mais importante do que o constrangimento, porque as características individuais, familiares e profissionais continuam a ser significativas. Além disso, os resultados demonstram que é importante compreender as preferências individuais dentro do contexto institucional. Portanto, nos debates teóricos e políticos sobre a participação das mulheres no mercado de trabalho, devemos ter em conta as possíveis barreiras que limitam as suas "escolhas" no mercado de trabalho.

Palavras-chave comparação interpaíses, padrões de trabalho feminino, dados de painéis longitudinais, preferências de trabalho.

Choice or constraint? Women's weekly working hours in comparative perspective

This article analyses the influence of individual working preferences on women's labour market behaviour in the Netherlands, Germany and the United Kingdom, addressing the question: to what extent do individual preferences have a causal effect on women's average weekly working hours? Using longitudinal panel data from all three countries, a fixed-effects model is applied to measure the effect of individual preferences in year $t-1$ on women's average weekly working hours in year $t$. The data is pooled from 1992 to 2002. After controlling for a number of individual, household and job characteristics we see that individual preferences are most influential in the Netherlands. However, the data do not support the idea that choice is more important than constraint because individual, household and job characteristics remain significant. In addition, the results demonstrate that it is important to understand individual preferences within the institutional context. Therefore, within the theoretical and policy debates about women's labour market participation we must consider possible barriers that hinder women when making labour market "choices".

$\underline{\text { Key-words }}$ cross-national comparison, female labour market patterns, longitudinal panel data, working preferences. 
Choix ou contrainte? Heures de travail hebdomadaires des femmes selon une approche comparée

Cet article analyse l'influence des préférences individuelles de travail dans le comportement des femmes sur le marché du travail en Hollande, en Allemagne et au Royaume-Uni, en posant une question : à quel point les préférences individuelles influencent-elles la moyenne d'heures de travail hebdomadaire des femmes ? En utilisant les données de panels longitudinaux des trois pays, un modèle d'effets fixes est appliqué pour mesurer l'effet des préférences individuelles au cours de l'année $t-1$ sur la moyenne des heures de travail hebdomadaires des femmes au cours de l'année $t$. Les données sont exploirées de 1992 à 2002. Après avoir contrôlé pour chaque individu les conditions d'habitation et professionnelles, nous pouvons voir que les préférences individuelles ont plus d'influence en Hollande. Cependant, les données ne permettent pas d'affirmer que le choix est plus important que la contrainte, car les caractéristiques individuelles, familiales et professionnelles demeurent importantes. En outre, les résultats démontrent qu'il est important de comprendre les préférences individuelles dans le contexte institutionnel. Par conséquent, dans les débats théoriques et politiques autour de la présence des femmes sur le marché du travail, nous devons tenir compte des éventuelles barrières qui limitent leurs " choix" sur le marché du travail.

Mots-clés comparaison inter-pays, standards de travail féminin, données de panels longitudinaux, préférences de travail.

Elección o limitante? Horas semanales de trabajo de las mujeres desde una perspectiva comparativa

Este artículo analiza la influencia de las preferencias individuales de trabajo en el comportamiento de las mujeres en el mercado de trabajo en Holanda, Alemania y Reino Unido, abordando la cuestión, ¿Hasta qué punto las preferencias individuales tienen un efecto causal en el promedio de las horas de trabajo semanales de las mujeres? Usando datos de muestras longitudinales de los tres países, se ha aplicado un modelo de efectos fijos para medir el efecto de las preferencias individuales en el año $t$ - 1 , en el promedio de las horas de trabajo semanales de las mujeres en el año $t$. Los datos son analizados de 1992 a 2002. Después de controlar para cada individuo las características habitacionales y profesionales, vemos que las preferencias individuales son más influyentes en Holanda. Sin embargo, los datos no sustentan la idea de que la elección sea más importante de que la limitante porque las características individuales, familiares y profesionales continúan a ser significativas. Además de eso, los resultados demuestran que es importante comprender las preferencias individuales dentro del contexto institucional. Por lo tanto, en los debates teóricos y políticos sobre la participación de las mujeres en el mercado de trabajo, debemos tener en 
cuenta las posibles barreras que limitan sus "elecciones" en el mercado de trabajo.

Palabras-clave comparación inter-países, padrones de trabajo femenino, datos de muestras longitudinales, preferencias de trabajo. 